\title{
Bilateral synovial cysts of the temporomandibular joint
}

\author{
Christina Buckley, ${ }^{1}$ Suzanne Beecher, ${ }^{1}$ Duncan Sleeman, ${ }^{2}$ Michael O'Shaughnessy ${ }^{1}$
}

${ }^{1}$ Department of Plastic and Reconstructive Surgery, Cork University Hospital Group, Cork, Ireland

${ }^{2}$ Oral and Maxillofacial Surgery Department, Cork University Hospital Group, Cork, Ireland

\section{Correspondence to}

Dr Suzanne Beecher,

suzub@hotmail.com

Accepted 26 June 2019

\section{SUMMARY}

Synovial cysts very rarely affect the temporomandibular joint (TMJ). On review of the literature, there are 29 reported cases of unilateral synovial cysts of the TMJ. We present a case of bilateral synovial cysts occurring at the TMJs.

\section{BACKGROUND}

Synovial cysts very rarely affect the temporomandibular joint (TMJ). To date, there have been 29 unilateral cases reported in the literature. We report the second bilateral case of synovial cysts occurring at the TMJs.

\section{CASE PRESENTATION}

An 80-year-old woman presented to our plastic surgery service with a 4 month history of a right pre-auricular mass. There was no associated pain or discharge. The mass occasionally fluctuated in size. There was no history of trauma to the area. She was asymptomatic and denied any changes to her dental occlusion or restriction in mouth opening.

On examination, there was a subcutaneous cystic mass present measuring $2 \times 2 \mathrm{~cm}$. This was visible in the right pre-auricular area when her mouth was closed. It was still visible, but less apparent, when she opened her mouth. On palpation, it was fixed to deeper structures.

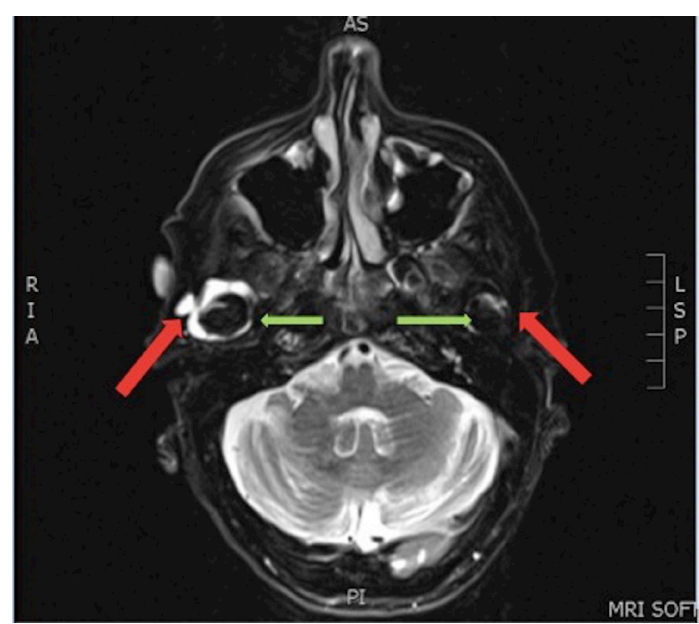

Figure 1 T2 fat suppressed axial MRI with contrast, displaying bilateral synovial cysts of the temporomandibular joints (TMJs). Green arrows: mandibular condyle within the TMJs. Red arrows: neck of synovial cysts.

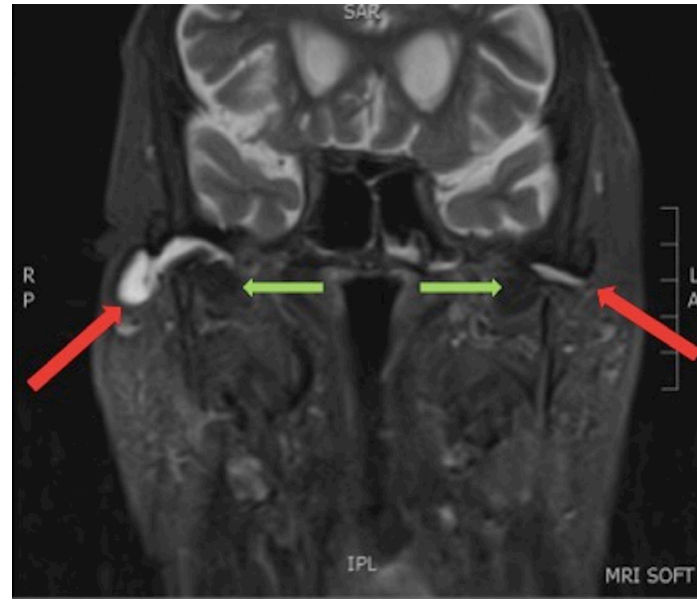

Figure 2 T2 coronal MRI demonstrating bilateral synovial cysts of the temporomandibular joints (TMJs). Green arrows: mandibular condyle within the TMJs. Red arrows: synovial cysts extruding into the soft tissue.

\section{INVESTIGATIONS}

Ultrasound examination was performed which demonstrated appearances in keeping with a bursa arising from the TMJ. An image guided fine needle aspiration was carried out which demonstrated the presence of macrophages, lymphocytes and synoviocytes.

Subsequent MRI examination was performed which demonstrated a very clear communication with the right TMJ (figure 1). In addition, there was evidence of the same process arising from the left TMJ (figures 1 and 2).

\section{DIFFERENTIAL DIAGNOSIS}

The radiological and cytological findings were in keeping with the diagnosis of synovial cyst affecting both TMJs.

\section{OUTCOME AND FOLLOW-UP}

In keeping with the patient's wishes, she was managed conservatively without intervention as the right side was asymptomatic and the left side was subclinical. She was asymptomatic and therefore did not require physiotherapy or pharmacological intervention. She was discharged to her general practitioner for follow-up.

\section{DISCUSSION}

On review of the literature, there are 29 reported cases of unilateral synovial cysts of the TMJ in the 
Table 1 Demographics of reported cases of unilateral synovial cysts of the temporomandibular joint

\begin{tabular}{|c|c|c|c|c|c|c|}
\hline Author & $\begin{array}{l}\text { Age } \\
\text { (years) }\end{array}$ & Gender & $\begin{array}{l}\text { Presenting } \\
\text { complaint }\end{array}$ & Duration & Imaging & Treatment \\
\hline $\begin{array}{l}\text { Janecka and } \\
\text { Conley }\end{array}$ & 50 & M & Swelling & 6 months & None & Surgical \\
\hline Kinklead $^{2}$ & 31 & $\mathrm{~F}$ & $\begin{array}{l}\text { Swelling } \\
\text { and pain }\end{array}$ & 4 months & X-ray & Surgical \\
\hline Reychler et al $\left.\right|^{3}$ & 30 & $\mathrm{~F}$ & Swelling & 2 weeks & X-ray & Surgical \\
\hline Bonacci et $a l^{4}$ & 46 & $M$ & $\begin{array}{l}\text { Swelling } \\
\text { and pain }\end{array}$ & 10 months & MRI, ultrasound & Arthroscopy \\
\hline Chang et $\left.\mathrm{a}\right|^{5}$ & 38 & $M$ & $\begin{array}{l}\text { Swelling } \\
\text { and pain }\end{array}$ & 2 weeks & CT & Surgical \\
\hline Chen et $a f^{6}$ & 58 & $M$ & Swelling & Few months & CT & Surgical \\
\hline Goudot et al ${ }^{7}$ & 65 & $M$ & $\begin{array}{l}\text { Reduced } \\
\text { mouth } \\
\text { opening }\end{array}$ & 1 year & MRI, CT & Surgical \\
\hline Lomeo et $a l^{8}$ & 47 & $\mathrm{~F}$ & $\begin{array}{l}\text { Swelling } \\
\text { and pain }\end{array}$ & 1 year & CT & Surgical \\
\hline $\begin{array}{l}\text { Moatemri } \\
\text { et al }\end{array}$ & 30 & $M$ & $\begin{array}{l}\text { Swelling } \\
\text { and pain }\end{array}$ & 1 year & СT & Surgical \\
\hline Neis et $a l^{11}$ & 57 & $M$ & $\begin{array}{l}\text { Ear pain } \\
\text { and aural } \\
\text { fullness }\end{array}$ & Unknown & $\mathrm{CT}, \mathrm{MRI}$ & Surgical \\
\hline Yang et $a l^{12}$ & 58 & $F$ & $\begin{array}{l}\text { Swelling, } \\
\text { pain }\end{array}$ & 2 months & CT & Surgical \\
\hline Spinzia et $a l^{10}$ & 45 & $\mathrm{~F}$ & $\begin{array}{l}\text { Swelling } \\
\text { and pain }\end{array}$ & 1 year & CT & Surgical \\
\hline Okochi et al ${ }^{13}$ & 31 & $M$ & $\begin{array}{l}\text { Swelling } \\
\text { and pain }\end{array}$ & 5 year & MRI & None \\
\hline Okochi et al ${ }^{13}$ & 20 & $\mathrm{~F}$ & Pain & 5 year & MRI & None \\
\hline $\begin{array}{l}\text { Vera-Sierra } \\
\text { et } a l^{14}\end{array}$ & 56 & $\mathrm{~F}$ & $\begin{array}{l}\text { Swelling } \\
\text { and pain }\end{array}$ & 6 months & CT & Surgical \\
\hline Ansari et a $\left.\right|^{15}$ & 63 & $\mathrm{~F}$ & Pain & Few months & MRI & Surgical \\
\hline Steen et $a l^{16}$ & 48 & $\mathrm{~F}$ & $\begin{array}{l}\text { Swelling } \\
\text { and pain }\end{array}$ & Few months & None & Surgical \\
\hline Verma et $a l^{17}$ & 33 & $\mathrm{~F}$ & $\begin{array}{l}\text { Swelling } \\
\text { and pain }\end{array}$ & 1 year & $\mathrm{CT}, \mathrm{MRI}$ & Surgical \\
\hline LaBan et $a l^{18}$ & 66 & $M$ & $\begin{array}{l}\text { Numb lip } \\
\text { and chin }\end{array}$ & 4 days & $\mathrm{CT}, \mathrm{MRI}$ & Surgical \\
\hline $\begin{array}{l}\text { Partridge et } \\
\text { a }\left.\right|^{19}\end{array}$ & nine patie & & Unknown & Unknown & Unknown & Surgical \\
\hline $\begin{array}{l}\text { El-Habbash } \\
\text { et al }{ }^{20}\end{array}$ & 56 & $F$ & $\begin{array}{l}\text { Swelling } \\
\text { and pain }\end{array}$ & Unknown & MRI & Surgical \\
\hline
\end{tabular}

English literature. ${ }^{1-20}$ This is the second case report of bilateral TMJ synovial cysts.

There was a slight female preponderance (56\%), and mean age at presentation was 46 years (range 20-66years). Our patient was older than those in the reported literature. Table 1 documents the demographics of the patients in all reported cases to date.

Most patients presented with swelling and/or pain in the pre-auricular area. One patient presented with reduced mouth opening. ${ }^{7}$ Acute numb lip and chin owing to mental nerve compression from the cyst was the cause of presentation in another case. ${ }^{18}$ Median symptom duration was 1 year (range 4 days to 5 years). In three of the cases, blunt trauma had preceded the formation of the cyst $(4$ months to 1 year prior to the onset of symptoms). ${ }^{235}$

In total, $87 \%$ of patients underwent imaging, with CT and MRI being the the most common modalities (44\% and $31 \%$, respectively).

The majority of patients in the case study cohort underwent surgical excision under general anaesthetic. No recurrences were reported. Only one perioperative complication was noted whereby the patient developed asystole owing to a severe trigeminocardiac reflex. ${ }^{20}$
Differential diagnoses exist for pre-auricular swellings. There can be particular difficulty differentiating a ganglion from a synovial cyst of the TMJ. Maribo et al found that even in the published literature, the terms have been used interchangeably. ${ }^{21}$ It should be noted that in the other published study claiming to report bilateral synovial cysts, the term was used interchangeably with ganglions. ${ }^{22}$ Synovial cysts have synoviocytes lining the walls of the cavity. With ganglions, the cells lining the cavity are immunohistochemically different and show signs of myofibroblasts. ${ }^{23}$ In our case, synoviocytes were found on aspiration, thus diagnosing a synovial cyst. In the case of the other reported bilateral synovial cyst, although the authors referred to them as ganglions in the body of their text, they must be regarded as true synovial cysts owing to the presence of synoviocytes on histological examination. ${ }^{22}$

In conclusion, synovial cysts of the TMJ should be included in the differential diagnosis of a pre-auricular swelling. This is the second reported case of bilateral synovial cysts of the TMJs.

\section{Learning points}

- Synovial cyst of the temporomandibular joint is a rare pathology. This is the second known bilateral case.

- Patients generally present with a pre-auricular swelling.

- Radiological investigations include ultrasound and MRI.

- Diagnosis relies on the presence of synoviocytes.

- Treatment can be conservative or surgical depending on the severity of symptoms.

Contributors All four authors (CB, SB, DS and $\mathrm{MO}$ ) have contributed to and approved of this submitted manuscript. CB is the submitting author.

Funding The authors have not declared a specific grant for this research from any funding agency in the public, commercial or not-for-profit sectors.

Competing interests None declared.

Patient consent for publication Next of kin consent obtained.

Provenance and peer review Not commissioned; externally peer reviewed.

\section{REFERENCES}

1 Janecka IP, Conley JJ. Synovial cyst of temporo-mandibular joint imitating a parotid tumour. (A case report). J Maxillofac Surg 1978;6:154-6.

2 Kinkead LR, Bennett JE, Tomich CE. A ganglion of the temporomandibular joint presenting as a parotid tumor. Head Neck Surg 1981;3:443-5.

3 Reychler H, Fievez C, Marbaix E. Synovial cyst of the temporomandibular joint. A case report. J Maxillofac Surg 1983;11:284-6.

4 Bonacci CE, Lambert BJ, Pulse $C L$, et al. Inflammatory synovial cyst of the temporomandibular joint: a case report and review of the literature. J Oral Maxillofac Surg 1996;54:769-73.

5 Chang YM, Chan CP, Kung Wu SF, et al. Ganglion cyst and synovial cyst of the temporomandibular joint. Two case reports. Int J Oral Maxillofac Surg 1997;26:179-81.

6 Chen M, Suzuki S, Siraki T, et al. Synovial cyst of the temporomandibular joint: report of a case. J Oral Pathol Med 1998;13(2):79-99.

7 Goudot P, Jaquinet AR, Richter M. Cysts of the temporomandibular joint. Int J Oral Maxillofac Surg 1999;28:338-40.

8 Lomeo PE, McDonald JE, Finneman J. Temporomandibular joint cyst as a preauricular mass. Am J Otolaryngol 2000;21:331-2.

9 Moatemri R, Farroukh O, Belajouza H, et al. [Synovial cyst of the temporomandibular joint]. Rev Stomatol Chir Maxillofac 2007;108(3):241-2.

10 Spinzia A, Panetta D, Russo D, et al. Synovial cyst of the temporomandibular joint: a case report and literature review. Int J Oral Maxillofac Surg 2011;40:874-7.

11 Neis J, Tehrani M, Dornhoffer JL. Synovial cyst of the temporomandibular joint: An unusual presentation. J Int Adv Otol 2010:6:116-9.

12 Yang XJ, Yang C, Chen MJ, et al. Preauricular transcondylar approach for basal cell adenoma of parotid coexist with ganglion cyst of the ipsilateral temporomandibular joint. J Craniofac Surg 2011;22:e23-e26.

13 Okochi K, Nakamura S, Tetsumura A, et al. Magnetic resonance imaging of temporomandibular joint cyst. Oral Surg Oral Med Oral Pathol Oral Radiol 2012;113:827-31. 
14 Vera-Sirera B, Tomás-Amerigo JA, Baquero C, et al. Synovial cysts of the temporomandibular joint: an immunohistochemical characterization and literature review. Case Rep Pathol 2013;2013. 508619.[PMC free article].

15 Ansari H, Robertson CE, Lane JI, et al. Auriculotemporal neuralgia secondary to TM synovial cyst: a rare presentation of a rare entity. Headache 2013;53:1662-5.

16 Steen MW, Hofstede DJ. Ganglion and synovial cyst of the temporomandibular joint: a case report and literature review. Plast Reconstr Surg Glob Open 2015:3:e524.

17 Verma S, Chambers I. Synovial cyst of the temporomandibular joint: a case report with surgical management and long-term follow-up. Oral Surg 2015;8:182-6.

18 LaBan MM, Wang AM, Chrisman A, et al. "Numb chin" syndrome: mental nerve mononeuropathy resulting from a synovial temporomandibular cyst. Am J Phys Med Rehabil 2015;94:e65.
19 Partridge JC, Cipriani N, Faquin WC, et al. Periarticular cysts of the temporomandibular joint are more frequently synovial than ganglion. J Oral Maxillofac Surg 2016;74:1396-402.

20 El-Habbash S, Padaki P, Bayoumi S, et al. Management of a temporomandibular joint synovial cyst in a case complicated by severe trigeminocardiac reflex. Ann R Coll Surg Engl 2018;100:e174-5.

21 Maribo Y, Stokbro K, Aagaard E, et al. Synovial cysts in the temporomandibular joint: a case report and critical review of the literature. J Oral Maxillofac Res 2019:10:1-9.

22 Farole A, Johnson MW. Bilateral synovial cysts of the temporomandibular joint. J Oral Maxillofac Surg 1991;49:305-7.

23 Giard M-C, Pineda C. Ganglion cyst versus synovial cyst? Ultrasound characteristics through a review of the literature. Rheumatol Int 2015;35:597-605.

Copyright 2019 BMJ Publishing Group. All rights reserved. For permission to reuse any of this content visit

https://www.bmi.com/company/products-services/rights-and-licensing/permissions/

BMJ Case Report Fellows may re-use this article for personal use and teaching without any further permission.

Become a Fellow of BMJ Case Reports today and you can:

- Submit as many cases as you like

- Enjoy fast sympathetic peer review and rapid publication of accepted articles

- Access all the published articles

Re-use any of the published material for personal use and teaching without further permission

Customer Service

If you have any further queries about your subscription, please contact our customer services team on +44 (0) 2071111105 or via email at support@bmj.com.

Visit casereports.bmj.com for more articles like this and to become a Fellow 